Bangladesh J. Plant Taxon. 21(1): 33-42, 2014 (June)

(C) 2014 Bangladesh Association of Plant Taxonomists

\title{
APPLICATION OF INTERNAL TRANSCRIBED SPACER OF NUCLEAR RIBOSOMAL DNA FOR IDENTIFICATION OF ECHINOPS MANDAVILLEI KIT TAN
}

\author{
Fahad M.A. Al-Hemaid, M. Ajmal Ali ${ }^{1}$, JoongKu LeE ${ }^{2}$, Gábor GyUlai $^{3}$ \\ AND ARUn K. PANDEY ${ }^{4}$ \\ Department of Botany and Microbiology, College of Science, King Saud University, \\ Riyadh 11451, Saudi Arabia
}

Keywords: Echinops mandavillei; Asteraceae; ITS; nrDNA; Endemic; Saudi Arabia.

\begin{abstract}
The present study explored the use of internal transcribed spacers (ITS) sequences (ITS1-5.8S-ITS2) of nuclear ribosomal DNA (nrDNA) for identification of Echinops mandavillei Kit Tan, an endemic species to Saudi Arabia. The sequence similarity search using Basic Local Alignment Search Tool (BLAST) and phylogenetic analyses of the ITS sequence of $E$. mandavillei Kit Tan showed high level of sequence similarity (98\%) with E. glaberrimus DC. (section Ritropsis). The novel primary sequence and the secondary structure of ITS2 of E. mandavillei could have a potential use for molecular genotyping.
\end{abstract}

\section{Introduction}

The genus Echinops L. belonging to the subtribe Echinopsinae of Cynareae, of the family Asteraceae comprise about 120 species (Vidović, 2011), and distributed in tropical Africa, the Mediterranean basin, temperate regions of Eurasia, Central Asia, Mongolia and North-eastern China, with the maximum number of species occurring in the Caucasus and the Middle East (Susanna and Garcia-Jacas, 2007). The genus received considerable interest for establishing natural groups with infrageneric classification (Sánchez-Jiménez et al., 2010). Morphological characters, like the pappus, which is a key taxonomic character of Cynareae, the type and density of indumentum on stems, leaf shapes and phyllaries are considered least significance in dissemination of Echinops species (Mozaffarian, 2006; Sánchez-Jiménez et al., 2010). In Saudi Arabia, there are nine Echinops species, viz. E. abuzinadianus Chaudhary, E. erinaceus Kit Tan, E. glaberrimus DC., E. hystrichoides Kit Tan, E. macrochaetus Fresen., E. mandavillei Kit Tan, E. sheilae Kit Tan, E. viscosus DC. and E. yemenicus Kit Tan. Of them, E. abuzinadianus, E. mandavillei and E. sheilae are endemic to Saudi Arabia, while remaining species have been reported from different geographic locations of Arabian Peninsula. E. mandavillei was reported to occur in Dahna, Summan and Nafud sands (Chaudhary, 2000).

The DNA sequence technology provides series of new data for molecular phylogeny and DNA barcoding which has now-a-days changed the paradigm of species identification (Ali and Choudhary, 2011; Ali et al., 2014). From the first report of the utility of the internal transcribed spacers (ITS) sequence of nuclear ribosomal DNA (nrDNA) in plants (Baldwin, 1992), it has been

${ }^{1}$ Corresponding author. E-mail: majmalali@rediffmail.com

${ }^{2}$ International Biological Material Research Center, Korea Research Institute of Bioscience and Biotechnology, Daejeon 305 806, South Korea

${ }^{3}$ Institute of Genetics and Biotechnology, St. István University, Gödöllo H-2103, Hungary

${ }^{4}$ Department of Botany, University of Delhi, Delhi 110007, India 
extensively used to distinguish even very closely related species (Chen et al., 2010; Yao et al., 2010). Moreover, in the last two decades, the ITS sequence technology has gained much attention, along with the smartest genes available for the molecular phylogeny and taxonomy (Ali et al., 2013).

The ITS sequence technology has been used for molecular phylogeny of Echinops (Garnatje et al., 2005), and series of other genera of Cynareae (Susanna et al., 1999; Vilatersana et al., 2000; Wang et al., 2005, 2007; Hidalgo et al., 2006); however, these studies did not include systematics of Echinops species occurring in Saudi Arabia. Hence, the present study aims to establish molecular signature of Echinops mandavillei Kit Tan based on ITS sequence of nrDNA.

\section{Materials and Methods}

Plant materials:

The leaf material of Echinops mandavillei Kit Tan was collected from herbarium specimen (Saudi Arabia, Al-Nafud, 29.4'N, 39.58'E, 5 May 1985, H.O. Al-Hassan 195) housed at National Herbarium and Genebank, National Agriculture and Animal Resources Research Centre, Riyadh, Saudi Arabia (RIY). The taxonomic identification of specimen was confirmed with the aid of Flora of Saudi Arabia (Chaudhary, 2000).

ITS sequences of 39 species of Echinops (Table 1) were retrieved from the GenBank database of NCBI (National Centre for Biotechnology Information; www.ncbi.nlm.nih.gov). Brachylaena discolor DC., from the tribe Tarchonantheae Kostel and Cardopatium corymbosum (L.) Pers. from the subtribe Cardopatiinae Less. were chosen as outgroups (Table 1) according to previous report based on molecular characters (Susanna et al., 2006; Sánchez-Jiménez et al., 2010).

Table 1. List of Echinops species used in the present study along with accession numbers.

\begin{tabular}{|c|c|c|}
\hline & Taxa & Accession number \\
\hline \multicolumn{3}{|c|}{ Ingroup } \\
\hline \multicolumn{3}{|c|}{ sect. Acantholepis (Less.) Jaub. \& Spach } \\
\hline 1. & Echinops acantholepis Jaub. \& Spach & AY8262223 \\
\hline \multicolumn{3}{|c|}{ sect. Chamaechinops Bunge } \\
\hline 2. & E. fastigiatus Kamelin \& Tscherneva & GU116503 \\
\hline 3. & E. humilis M. Bieb & GU116514 \\
\hline 4. & E. integrifolius Kar. \& Kir. & GU116517 \\
\hline \multicolumn{3}{|c|}{ sect. Echinops } \\
\hline 5. & E. arachniolepis Rech. f. & GU116486 \\
\hline 6 & E. dahuricus Fisch. & GU116493 \\
\hline 7. & E. freitagii Rech. f. & GU116504 \\
\hline 8. & E. kotschyi Boiss. & GU116520 \\
\hline 9. & E. latifolius Tausch & GU116521 \\
\hline 10. & E. nizvanus Rech.f. & GU116530 \\
\hline 11. & E. parviflorus Boiss. \& Buhse & GU116533 \\
\hline 12. & E. przewalskyi Iljin & GU116535 \\
\hline 13. & E. ritrodes Bunge & GU116539 \\
\hline 14. & E. setifer Iljin & GU116540 \\
\hline 15. & E. sphaerocephalus L. & GU116541 \\
\hline 16. & E. spiniger Iljin & GU116542 \\
\hline & E. transcaucasicus Iljin & GU116546 \\
\hline
\end{tabular}


Table 1 contd.

\begin{tabular}{|c|c|}
\hline Taxa & Accession number \\
\hline \multicolumn{2}{|l|}{ sect. Hamolepis R. E. Fr. } \\
\hline \multicolumn{2}{|l|}{ sect. Hololeuce Rech. f. } \\
\hline \multicolumn{2}{|l|}{ sect. Nanechinops Bunge } \\
\hline \multicolumn{2}{|l|}{ sect. Oligolepis Bunge } \\
\hline 21. E. cephalotes DC. & GU116487 \\
\hline E. cornigerus DC. & GU116552 \\
\hline E. echinatus Roxb. & GU116497 \\
\hline E. ghoranus Rech. f. & GU116508 \\
\hline E. griffithianus Boiss. & GU116512 \\
\hline E. ilicifolius Bunge & GU116516 \\
\hline E. leucographus Bunge & GU116522 \\
\hline 28. E. lipskyi Iljin & GU116523 \\
\hline \multicolumn{2}{|l|}{ sect. Phaeochaete Bunge } \\
\hline $\begin{array}{l}\text { 29. E. longifolius A. Rich } \\
\text { sect. Psectra Endl. }\end{array}$ & GU116524 \\
\hline $\begin{array}{l}\text { 30. E. strigosus L. } \\
\text { sect. Ritropsis Greuter \& Rech. f. }\end{array}$ & AY5386532 \\
\hline 31. E. chardinii Boiss. \& Buhse & GU116490 \\
\hline E. dichrous Boiss. \& Hausskn. & GU116495 \\
\hline E. endotrichus Rech.f. & GU116500 \\
\hline E. gaillardotii Boiss. & GU116507 \\
\hline E. glaberrimus DC. & GU116509 \\
\hline E. mandavillei Kit Tan & KJ187107 \\
\hline E. orientalis Trautv. & GU116532 \\
\hline E. spinosissimus Turra & HE687348 \\
\hline 39. E. tenuisectus Rech. f. & GU116551 \\
\hline \multicolumn{2}{|l|}{ sect. Terma Endl. } \\
\hline 40. E. exaltatus Schrad. & GU116501 \\
\hline \multicolumn{2}{|l|}{ Outgroup } \\
\hline 41. Brachylaena discolor DC. & AY8262363 \\
\hline 42. Cardopatium corymbosum (L.) Pers. & AY 8262383 \\
\hline
\end{tabular}

\section{DNA isolation and amplification:}

Genomic DNA was extracted from $10 \mathrm{mg}$ silica gel-dried leaves using the protocol of DNeasy Plant Mini kit (QIAGEN, Valencia, CA, USA). The ITS regions were amplified using the primers ITS1 and ITS4 as described by White et al. (1990). Double-stranded polymerase chain reaction (PCR) products were produced through 35 cycles of $95^{\circ} \mathrm{C}$ for $1 \mathrm{~min}, 48^{\circ} \mathrm{C}$ for $1 \mathrm{~min}$ and $72^{\circ} \mathrm{C}$ for $1 \mathrm{~min}$, with a $10 \mathrm{~min}$ final extension cycle at $72^{\circ} \mathrm{C}$. PCR products were purified with SolGent PCR Purification kit-Ultra (SolGent, Daejeon, South Korea), and forwarded to sequencing using the same primers, $2 \mathrm{~L}$ BigDye, $1 \mu \mathrm{l}$ primer $(20 \mathrm{pM})$, template DNA and purified water to reach a $10 \mu \mathrm{l}$ reaction volume. Cycle sequencing used was 25 cycles of $96^{\circ} \mathrm{C}$ for $10 \mathrm{~s}, 50^{\circ} \mathrm{C}$ for $5 \mathrm{~s}$, and $60^{\circ} \mathrm{C}$ for $4 \mathrm{~min}$. 
DNA sequencing and data analysis:

DNA sequencing was performed by ABI Prism 377 automated DNA sequencer (Applied Biosystems, Foster City, CA, USA). Each sample was sequenced in the sense and anti-sense direction. The nucleotide sequences of both DNA strands were obtained and analyzed by Sequence Navigator (Perkin-Elmer/Applied Biosystems) to ensure accuracy of the base pair sequences. The sequence was submitted to GenBank (accession number KJ187107).

Sequence alignments were performed using CLUSTAL X, version 1.81 (Thompson et al., 1997), and sequence alignments were subsequently adjusted manually using BioEdit (Hall, 1999). Gaps were treated as missing data in phylogenetic analyses. The maximum parsimony and neighbour-joining analyses with 1,000 bootstrap replicates (Felsenstein, 1985) were performed using PAUP* 4.0b10 (Swofford, 2002). The boundaries between ITS1, 5.8S and ITS2 gene were determined according to the ITS sequences of Echinops available in GenBank. The ITS2 database (http://its2.bioapps.biozentrum.uni-wuerzburg.de/) was used to predict the secondary structures (Koetschan et al., 2012).

\section{Results and Discussion}

The ITS region (ITS1-5.8S-ITS2) of Echinops mandavillei Kit Tan sequenced in the present study was found $634 \mathrm{bp}$, where ITS1 region $252 \mathrm{bp}$ (GC content 54\%), 5.8S gene $164 \mathrm{bp}$ (GC content 53\%), and ITS2 region 218 bp (GC content 50\%). The BLAST search of ITS sequence of E. mandavillei Kit Tan showed maximum identity (98\%) with E. glaberrimus DC. Parsimony analysis of the entire ITS region resulted in 431 maximally parsimonious trees with consistency index of 0.691 , homoplasy index of 0.459 , and retention index of 0.763 . The phylogenetic tree constructed by the present analyses shows Echinops to be monophyletic (bootstrap support 100\%; Fig. 1). The tree also provides a clear resolution at the sectional level and the result confirms an earlier report (Sánchez-Jiménez et al., 2010), and E. mandavillei Kit Tan nested within the clade of the section Ritropsis (Fig. 1). Figure 2 illustrates specific nucleotide differences between $E$. mandavillei Kit Tan and E. glaberrimus DC., in total seven SNPs (four nucleotides in ITS1 region, i.e. at the alignment position 11, 81, 226 and 234, and three nucleotides in ITS2 region, i.e. at the alignment position 4, 58 and 165) were observed.

Table 2. Loci of SNPs (single nucleotide polymorphism) ITS sequences of $E$. mandavillei compared to E. glaberrimus.

\begin{tabular}{lcc}
\hline Region & Position in sequence alignment & E. mandaville $\rightarrow$ E. glaberrimus \\
\hline \multirow{3}{*}{ ITS1 } & $11^{\text {th }}$ & $\mathrm{T} \rightarrow \mathrm{C}$ \\
& $81^{\text {th }}$ & $\mathrm{G} \rightarrow \mathrm{R}$ \\
& $226^{\text {th }}$ & $\mathrm{T} \rightarrow \mathrm{C}$ \\
$234^{\text {th }}$ & $\mathrm{C} \rightarrow \mathrm{T}$ \\
\hline \multirow{3}{*}{ ITS2 } & $4^{\text {th }}$ & $\mathrm{A} \rightarrow \mathrm{C}$ \\
& $58^{\text {th }}$ & $\mathrm{A} \rightarrow \mathrm{G}$ \\
& $165^{\text {th }}$ & $\mathrm{T} \rightarrow \mathrm{C}$ \\
\hline
\end{tabular}

The secondary structures of ITS2 region of E. mandavillei Kit Tan and E. glaberrimus DC. were constructed and compared (Fig. 3 A-B), which contained a central ring (primary ring) and four helices. However, the two structures differed in the four helical regions, in stem loop numbers, sizes, position, and screw angle. On the basis of the ITS2 secondary structure, E. mandavillei Kit Tan could be discriminative from other species of the genus. 


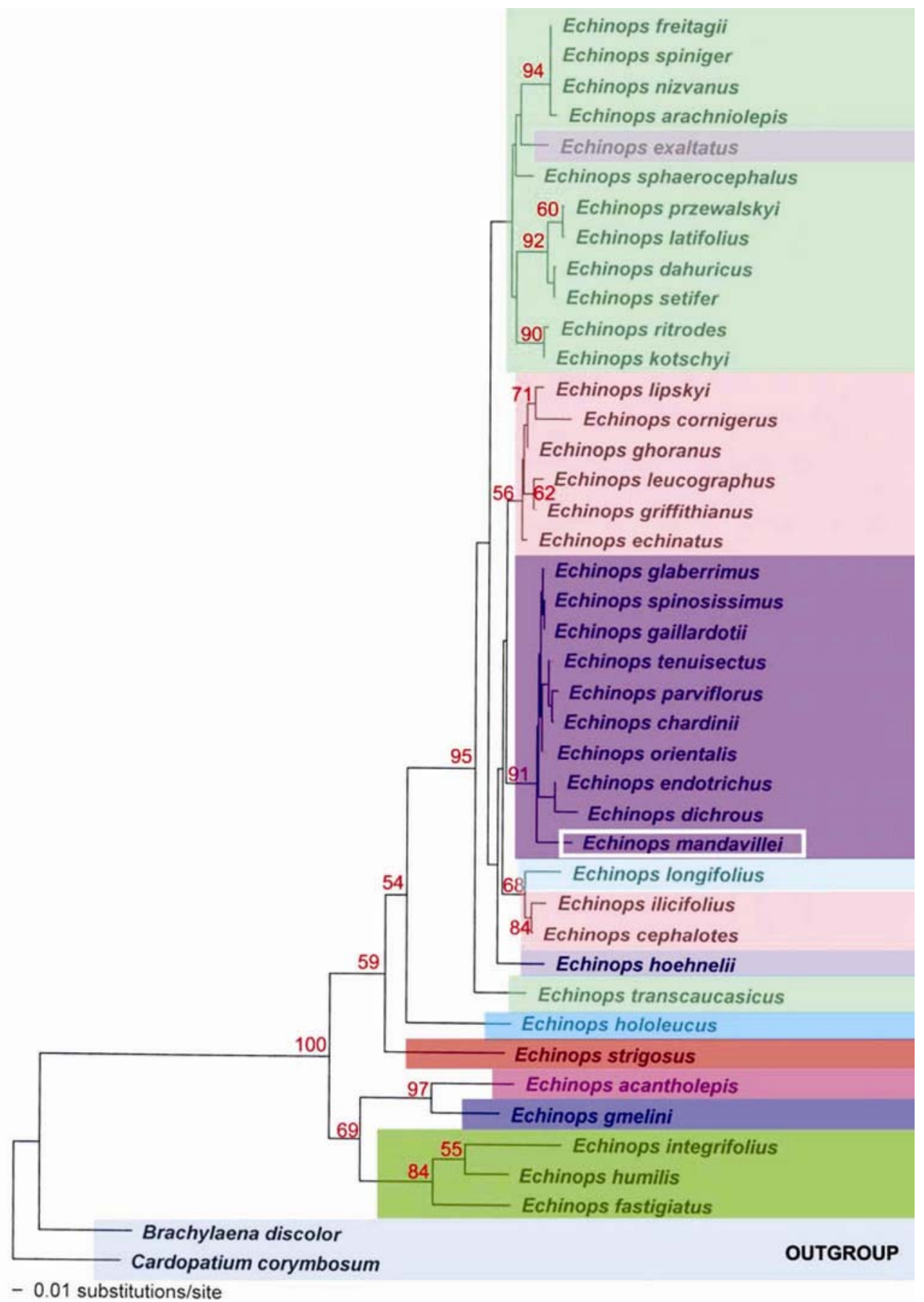

Fig. 1. Neighbour joining tree of Echinops species including E. mandavillei inferred from ITS sequences of nrDNA. Bootstrap values greater than $50 \%$ in 1,000 bootstrap replicates are shown above lines. 


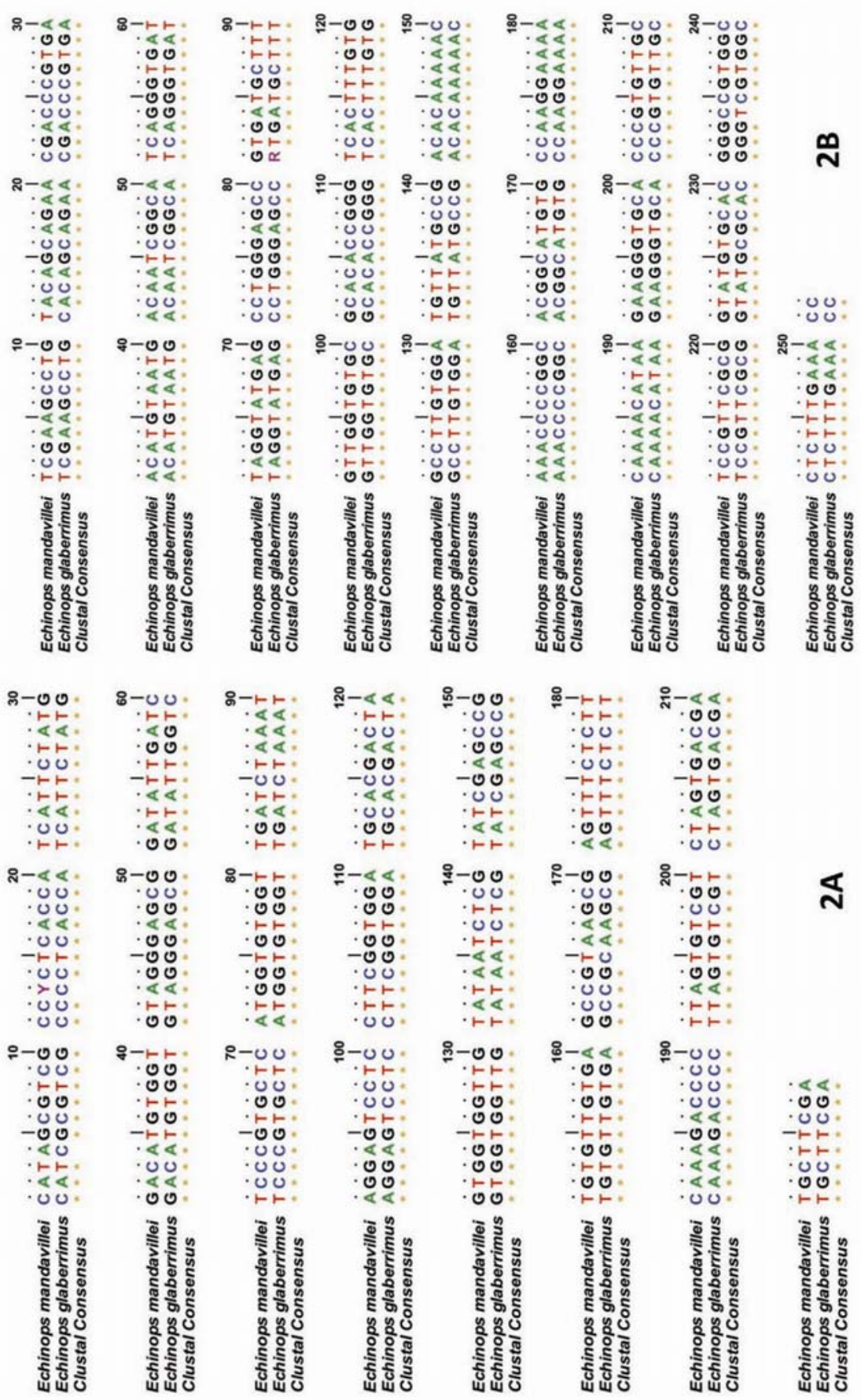

Fig. 2A. Alignments of ITS1 sequences of E. mandavillei compared to E. glaberrimus, B. Alignments of ITS2 sequences of E. mandavillei compared to E. glaberrimus. Gaps in clustal line indicate nucleotide differences. 


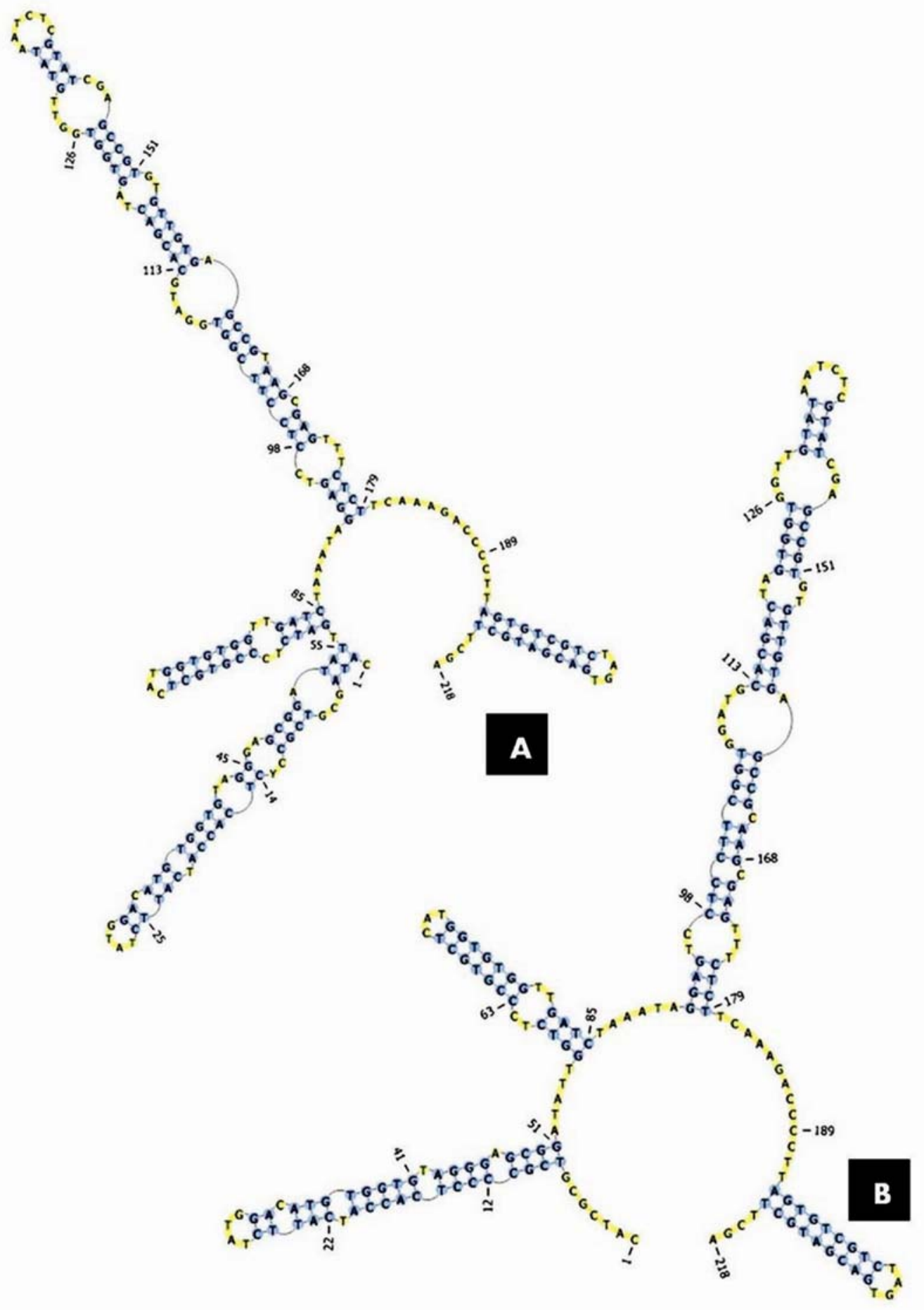

Fig. 3. The secondary structures of the ITS2 regions of E. mandavillei (A) compared to E. glaberrimus (B). 
The morphological identification depends on sufficient experience and can easily be affected by the geographical environment and biocoenosis (Marcon et al., 2005; Rai et al., 2012). In contrast, DNA sequence is hardly influenced by environmental characteristics and developmental stages (Liu et al., 2011); and therefore, the DNA barcoding may be an effective supplement to traditional/classical morphological methods (see Hebert et al., 2003). The species identification using DNA barcodes has been successfully used across the algae, fungi, plants, and animals, hence; the DNA barcoding has now been proven useful in biodiversity assessment, biomonitoring, forensics, illegal trade of endangered species and their products, ecology, medicinal and poisonous plants and conservation genetics (see Hebert et al., 2003; Fišer Pečnikar and Buzan, 2014; Ali et al., 2014).

DNA barcoding efforts worldwide have resulted in the formation of the Consortium for the Barcode of Life (CBOL), and the Barcode of Life Database (BOLD), which contain more than 2.7 million records, with 2 million barcodes belonging to over 170,000 species (Ratnasingham and Hebert, 2007; BOLD Systems, 2013). The China Plant BOL Group has proposed that ITS1/ITS2 should be incorporated into the core of barcode for seed plants (Li et al., 2011). In the present study, we supplied the ITS barcode of E. mandavillei Kit Tan which is new for GenBank databases. An increasing number of studies also suggest that DNA secondary structures are crucial for genomic stability and cellular processes, such as transcription (Bochman et al., 2012; Salvi and Mariottini, 2012), and our study has also provided new data of E. mandavillei Kit Tan for this purposes.

\section{Acknowledgements}

The authors would like to extend their sincere appreciation to the Deanship of Scientific Research at King Saud University for the funding of this research through the Research Group Project No. RGP-VPP-195.

\section{References}

Ali M.A, Al-Hemaid, F.M., Choudhary, R.K., Lee, J., Kim, S.Y. and Rub, M.A. 2013. Status of Reseda pentagyna Abdallah \& A.G. Miller (Resedaceae) inferred from combined nuclear ribosomal and chloroplast sequence data. Bangladesh J. Plant Taxon. 20(2): 233-238.

Ali, M.A., Gábor, G., Norbert, H., Balázs, K., Al-Hemaid, F.M.A., Pandey, A.K. and Lee, J. 2014. The changing epitome of species identification- DNA barcoding. Saudi J. Biol. Sci. http://dx.doi.org/ 10.1016/j.sjbs.2014.03.003

Ali, M.A. and Choudhary R.K. 2011. India needs more plant taxonomists. Nature 471: 37.

Baldwin, B.G. 1992. Phylogenetic utility of the internal transcribed spacers of nuclear ribosomal DNA in plants: an example from the Compositae. Mol. Phylogenet. Evol. 1: 3-16.

Bochman, M.L., Paeschke, K. and Zakian, V.A. 2012. DNA secondary structures: stability and function of Gquadruplex structures. Nat. Rev. Genet. 13: 770-780.

BOLD Systems 2013. BOLD Systems v3. http://www.boldsystems.org/ (Retrieved on 6 May 2014)

Chaudhary, S. 2000. Echinops. In: Chaudhary, S. (Ed.), Flora of the Kingdom of Saudi Arabia. Ministry of Agriculture and Water, National Herbarium, National Agriculture and Water Research Center, Riyadh, Saudi Arabia, Vol. II (3), pp. 194-199.

Chen, S., Yao, H., Han, J., Liu, C., Song, J., Shi, L., Zhu, Y., Ma, X., Gao, T., Pang, X., Luo, K., Li, Y., Li, X., Jia, X., Lin, Y. and Leon, C. 2010. Validation of the ITS2 region as a novel DNA barcode for identifying medicinal plant species. PLoS ONE 5(1): e8613. 
Felsenstein, J. 1985. Confidence limits on phylogenies: an approach using the bootstrap. Evolution 39: 783791.

Fišer Pečnikar, Z. and Buzan, E.V. 2014. 20 years since the introduction of DNA barcoding: from theory to application. J. Appl. Genet. 55: 43-52.

Garnatje, T., Susanna, A., Garcia-Jacas, N., Vilatersana, R. and Vallès, J. 2005. A first approach to the molecular phylogeny of the genus Echinops L. (Asteraceae): sectional delimitation and relationships with the genus Acantholepis Less. Folia Geobot. 40: 407-419.

Hall, T.A. 1999. BioEdit: A user-friendly biological sequence alignment editor and analysis program for Windows 95/98/NT. Nuc. Acids Symp. Ser. 41: 95-98.

Hebert, P.D.N., Cywinska, A., Ball, S.L. and deWaard, J.R. 2003. Biological identifications through DNA barcodes. Proc. Biol. Sci. 270: 313-321.

Hidalgo, O., Garcia-Jacas, N., Garnatje, T. and Susanna, A. 2006. Phylogeny of Rhaponticum (Asteraceae, Cardueae-Centaureinae) and related genera inferred from nuclear and chloroplast DNA sequence data: Taxonomic and biogeographic implications. Ann. Bot. 97: 705-714.

Koetschan, C., Hackl, T., Müller, T., Wolf, M., Förster, F. and Schultz, J. 2012. ITS2 database IV: Interactive taxon sampling for Internal Transcribed Spacer 2 based phylogenies. Mol. Phylogenet. Evol. 63: 585588.

Li, D.Z., Gao, L.M., Li, H.T., Wang, H., Ge, X.J., Liu, J.Q., Chen, Z.D., Zhou, S.L., Chen, S.L., Yang, J.B., Fu, C.X., Zeng, C.X., Yan, H.F., Zhu, Y.J., Sun, Y.S., Chen, S.Y., Zhao, L., Wang, K., Yang, T. and Duan, G.W. 2011. Comparative analysis of a large dataset indicates that internal transcribed spacer (ITS) should be incorporated into the core barcode for seed plants. Proc. Natl. Acad. Sci. USA 108: 19641-19646.

Liu, C., Liang, D., Gao, T., Pang, X., Song, J., Yao, H., Han, J., Liu, Z., Guan, X., Jiang, K., Li, H. and Chen, S. 2011. PTIGS-IdIt, a system for species identification by DNA sequences of the $p s b \mathrm{~A}-\operatorname{trn} \mathrm{H}$ intergenic spacer region. BMC Bioinformatics 12: S4.

Marcon, A.B., Barros, I.C. and Guerra, M. 2005. Variation in chromosome numbers, CMA bands and 45S rDNA sites in species of Selaginella (Pteridophyta). Ann. Bot. 95: 271-276.

Mozaffarian, V. 2006. A taxonomic survey of Echinops L. tribe Echinopeae (Asteraceae) in Iran: 14 new species and diagnostic keys. Iranian J. Bot. 11: 197-239.

Rai, P.S., Bellampalli, R., Dobriyal, R.M., Agarwal, A., Satyamoorthy, K. and Narayana, D.A. 2012. DNA barcoding of authentic and substitute samples of herb of the family Asparagaceae and Asclepiadaceae based on the ITS2 region. J. Ayurveda Integr. Med. 3: 136-140.

Ratnasingham, S. and Hebert, P.D.N. 2007. Bold: The Barcode of Life Data System (http://www.barcodinglife.org). Mol. Ecol. Notes 7: 355-364.

Salvi, D. and Mariottini, P. 2012. Molecular phylogenetics in 2D: ITS2 rRNA evolution and sequencestructure barcode from Veneridae to Bivalvia. Mol. Phylogenet. Evol. 65: 792-798.

Sánchez-Jiménez, I., Lazkov, G.A., Hidalgo, O. and Garnatje, T. 2010 Molecular systematics of Echinops L. (Asteraceae, Cynareae): A phylogeny based on ITS and trnL-trnF sequences with emphasis on sectional delimitation. Taxon 59(3): 698-708.

Susanna, A. and Garcia-Jacas, N. 2007. The tribe Cardueae. In: Kadereit, J.W. and Jeffrey, C. (Eds), The families and genera of vascular plants, Vol. 8, Flowering plants; Eudicots; Asterales. Heidelberg, Springer, pp. 135-158.

Susanna, A., Garcia-Jacas, N., Hidalgo, O., Vilatersana, R. and Garnatje, T. 2006. The Cardueae (Compositae) revisited: Insights from ITS, $\operatorname{trn} \mathrm{L}-\operatorname{trn} \mathrm{F}$, and $m a t \mathrm{~K}$ nuclear and chloroplast DNA analysis. Ann. Missouri Bot. Gard. 93: 150-171.

Susanna, A., Garnatje, T. and Garcia-Jacas, N. 1999. Molecular phylogeny of Cheirolophus (Asteraceae: Cardueae-Centaureinae) based on ITS sequences of nuclear ribosomal DNA. Plant Syst. Evol. 214: 147-160. 
Swofford, D.L. 2002. PAUP* (v. 4.0b10). Phylogenetic analysis using parsimony (* and other methods). Sinauer Associates, Sunderland.

Thompson, J.D., Gibson, T.J., Plewniak, F., Jeanmougin, F. and Higgins, D.G. 1997. The CLUSTAL X windows interface: Flexible strategies for multiple sequence alignment aided by quality analysis tools. Nucleic Acids Res. 24: 4876-4882.

Vidović, B. 2011. A new Aceria species (Acari: Eriophyoidea) on Echinops ritro L. subsp. ruthenicus (M. Bieb.) Nyman (Asteraceae) from Serbia and a supplement to the original description of Aceria brevicincta (Nalepa 1898). Zootaxa 2796: 56-66.

Vilatersana, R., Susanna, A., Garcia-Jacas, N. and Garnatje, T. 2000. Generic delimitation and phylogeny of the Carduncellus-Carthamus complex (Asteraceae) based on ITS sequences. Plant Syst. Evol. 221: 89105.

Wang, Y.J., Liu, J.Q. and Miehe, G. 2007. Phylogenetic origins of the Himalayan endemic Dolomiaea, Diplazoptilon and Xanthopappus (Asteraceae: Cardueae) based on three DNA regions. Ann. Bot. 99: 311-322.

Wang, Y.J., Pan, J.T., Liu, S.W. and Liu, J.Q. 2005. A new species of Saussurea (Asteraceae) from Tibet and its systematic position based on ITS sequence analysis. Bot. J. Linn. Soc. 147: 349-356.

White, T.J., Bruns, T., Lee, S. and Taylor, J. 1990. Amplification and direct sequencing of fungal ribosomal RNA genes for phylogenetics. In: Innis, M.A., Gelfand, D.H., Sninksky, J.J. and White, T.J. (Eds), PCR protocols: a guide to method and amplifications. Academic Press, San Diego, California, pp. 315-322.

Yao, H., Song, J., Liu, C., Luo, K., Han, J., Li, Y., Pang, X., Xu, H., Zhu, Y., Xiao, P. and Chen, S. 2010. Use of ITS2 region as the universal DNA barcode for plants and animals. PLoS ONE 5(10): e13102.

(Manuscript received on 7 February 2014; revised on 9 May 2014) 